\title{
Dynamics of dye release from nanocarriers of different types in model cell membranes and living cells
}

\author{
T. N. Tkacheva, S .L. Yefimova, V. K. Klochkov, A. V. Sorokin, Yu. V. Malyukin \\ Institute for Scintillation Materials NAS of Ukraine \\ 60, Lenin Ave., Kharkiv, Ukraine, 61001 \\ ephimova@isma.kharkov.ua
}

\begin{abstract}
Aim. To study the dynamics of lipophilic content release from nanocarriers of different types, organic molecular ensembles and inorganic nanoparticles (NPs) in vitro experiments. Methods. Two-channel ratiometric fluorescence detection method based on Forster Resonance Energy Transfer, fluorescent spectroscopy and microspectroscopy have been used. Results. It has been found that the profiles of lipophilic dyes release from organic nanocarriers (PC liposomes and SDS micelles) and inorganic ones (GdYVO $\mathrm{Eu}_{4}^{3+}$ and $\mathrm{CeO}_{2} \mathrm{NPS}$ ) are well fitted by the first-order reaction kinetics in both model cell membranes and living cells (rat hepatocytes). The dye release constants $(\mathrm{K})$ and half-lives $\left(t_{1 / 2}\right)$ were analyzed. Conclusions. $G d Y V O_{4}: E u^{3+}$ and $\mathrm{CeO}_{2} \mathrm{NPs}_{\text {s }}$ ave been shown to provide faster lipophilic content release in model cell membranes as compared to PC liposomes. Negatively charged or lipophilic compounds added into nanocarriers can decrease the rate of lipophilic dyes release. Specific interaction of $\mathrm{GdYVO}_{4}: \mathrm{Eu}^{3+} \mathrm{NPS}$ with rat hepatocytes has been observed.
\end{abstract}

Keywords: nanocarries, Forster Resonance Energy Transfer, dye release, model cell membranes, living cells.

Introduction. Nano-drugs (NDs) are the important products of rapidly developing nanotechnologies in biology and medicine field [1-4]. NDs are composed of a nano-scale matrix (carriers, platform) and therapeutic or any other active compounds (diagnostics or imaging agents) encapsulated in a carrier or adsorbed on its surface $[2,4,5]$. A nanocarrier serves as a delivery system providing targeted drug delivery (passive and active targeting) to the pathological area and their controlled release that increases drastically the efficiency of therapy [1-5]. Such nanomaterials have unique physicochemical properties, such as ultra small size, large surface area to mass ratio, and high reactivity, which can be used to overcome some of the limitations found in traditional therapeutic and diagnostic agents [6]. Today, a variety of nanocarriers such as polymeric micelles, liposomal vesicles, dendrimeres, inorganic nanoparticles, etc. have been attempted as drug-delivery systems for treatment of cancer, some infectious, inherited and incurable diseases [1-6].

(C) Institute of Molecular Biology and Genetics, NAS of Ukraine, 2014
Recently we have reported the method of $\mathrm{GdYVO}_{4}: \mathrm{Eu}^{3+}$ nanoparticles (NPs) synthesis with controlled size and shape [7]. NPs can be obtained as aqueous colloidal solutions which are transparent in incident light and brightly luminescent under the laser excitation with an appropriate wavelength. It was also found that cationic dye molecules interact with negatively charged NPs that causes neutralization of NPs surface charge and provokes the formation of hybrid dye/NPs complexes $[8$, 9]. Using microspectroscopic technique, we found that spherical $\mathrm{GdYVO}_{4}: \mathrm{Eu}^{3+} \mathrm{NPs}$ with the average diameter of $2 \mathrm{~nm}$ accumulate in rat hepatocytes nuclei in situ and in isolated nuclei of the cells and exhibit tropism to nuclear structural components [10]. Our findings are very promising for biomedical applications of orthovanadate NPs as a nano-scale platform for new anti-cancer NDs.

In spite of amazing promises of NDs, many challenges remain in their clinical applications. One of the obstacles is a requirement of a better understanding of the interactions of nanomaterials with biological systems, which will facilitate the engineering of their properties specific to biomedical applications. 
Another important aspect in the NDs development is controlling the rate of active compound release from the carrier [11].

In the present paper, we report in vitro study of the dyes $/ \mathrm{GdYVO}_{4}: \mathrm{Eu}^{3+} \mathrm{NPs}$ complexes interaction with model membranes and living cells (rat hepatocytes) and the dye release kinetics using fluorescent spectroscopy and microspectroscopic techniques. For comparison, we used other inorganic NPs $\left(\mathrm{CeO}_{2} \mathrm{NPs}\right)$ and organic ones (liposome vesicles, surfactant micelles). The dyes used mimic hydrophobic drug molecules. To study the dye release in dynamics, we used a pair of dyes, so-called FRET-pair (Forster Resonance Energy Transfer [12]), DiO and DiI dye molecules, encapsulated in or adsorbed on nanocarriers and a $\lambda$-ratiometry method of fluorescence detection based on fluorescence recording at two wavelengths [13-15].

Materials and methods. Chemicals. Fluorescent hydrophobic dyes 3,3'-dioctadecyloxacarbocyanine perchlorate (DiO), 1,1'-dioctadecyl-3,3,3',3'-tetrame thylindocarbocyanine perchlorate (DiI) (Fig. 1), L- $\alpha$ phosphatidylcholine (PC) from egg yolk and sodium dodecylsulfate (SDS) were purchased from «Sigma-Aldrich» (USA) and used without purification. Chloroform («Sigma-Aldrich») used to prepare lipid and dye stock solutions was a spectroscopic grade product. DMSO («Sigma-Aldrich») was also of spectroscopic grade. To prepare aqueous solutions of the dyes with nanocarriers, double distilled water was used.

NPs synthesis. The aqueous colloidal solutions of $\mathrm{GdYVO}_{4}: \mathrm{Eu}^{3+}$ and $\mathrm{CeO}_{2}$ were synthesized according to the method reported earlier [7,9]. NPs were characterized using Transmission Electron Microscopy (TEM$125 \mathrm{~K}$ electron microscope, «Selmi», Ukraine). Zeta potentials were measured using a ZetaPALS/BI-MAS analyzer («Brookhaven Instruments Corp.», USA) operated in phase analysis light scattering mode. In the present work the spherical $\mathrm{GdYVO}_{4}: \mathrm{Eu}^{3+}(d=2 \mathrm{~nm} ; \zeta$ potential $-20.94 \pm 1.27 \mathrm{mV})$ and $\mathrm{CeO}_{2}(d=2 \mathrm{~nm} ; \zeta$ potential $-24 \pm 1.07 \mathrm{mV}$ ) NPs were used.

Preparation of SDS micelles with DiO and DiI dyes. The concentration of the surfactant in the solutions was $1 \cdot 10^{-2} \mathrm{M}$. The concentration of the dyes in the water-micelles solutions was $2 \cdot 10^{-5} \mathrm{M}$. First, stock solution of each dye in chloroform of $1 \cdot 10^{-3} \mathrm{M}$ concentration was prepared. To prepare the solutions for measurements,

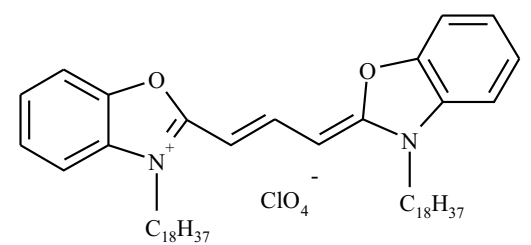

$B$

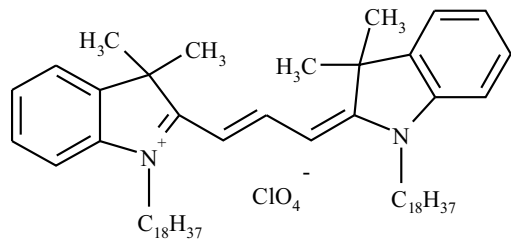

Fig. 1. Structural formulas of the dyes: $A-\mathrm{DiO} ; B-\mathrm{DiI}$

$3 \mathrm{mg}$ of SDS were mixed in a flask with the required amount of the dye stock solution. After chloroform evaporation the required amount of double distilled water was added. The solutions were heated to $80^{\circ} \mathrm{C}$ to ensure the uniform distribution of the components and then cooled to room temperature.

Preparation of lipid vesicles with $\mathrm{DiO}$ and DiI dyes. Unilamellar PC lipid vesicles containing DiO and DiI dyes were prepared by the extrusion method [16]. Appropriate amount of PC $(40 \mathrm{mg} / \mathrm{ml})$ and dyes $\left(10^{-3} \mathrm{M}\right)$ stock solutions in chloroform was mixed in a flask and dried until complete chloroform evaporation. The thin lipiddyes film was then hydrated with $2 \mathrm{ml}$ of double distilled water. Final concentration of PC was $1 \cdot 10^{-3} \mathrm{M}$. The obtained lipid-dyes suspension was finally extruded through $100 \mathrm{~nm}$ pore size polycarbonate filter using a mini-extruder («Avanti Polar Lipids, Inc.», USA). The concentration of each dye in liposomal suspension was $2 \cdot 10^{-5} \mathrm{M}$.

If PC liposomes contain SDS, $10 \%$ of SDS (with respect to PC weight) were added at the stage of lipiddyes film formation.

Preparation of dyes/NPs complexes. Water colloidal solutions of $\mathrm{GdYVO}_{4}: \mathrm{Eu}^{3+}$ or $\mathrm{CeO}_{2}(0.5 \mathrm{~g} / \mathrm{l}) \mathrm{NPs}$ and $\mathrm{DiO}$ and DiI dyes $\left(3 \cdot 10^{-3} \mathrm{M}\right)$ stock solutions in isopropyl were mixed in a flask. The mixture was carefully stirred using a rotary evaporator (Rotavapor R-3, «Buchi», Switzerland) during $1 \mathrm{~h}$ to complete evaporation of isopropyl. The final concentration of each dye was $2 \cdot 10^{-5} \mathrm{M}$.

If the complexes contain cholesterol, its solution in isopropyl $(0.1 \mathrm{M})$ was added at the stage of mixture preparation.

Cell labeling procedure. Isolated rat hepatocytes from male Wistar rats were obtained by the method des- 
cribed by Wang after dissociation of the liver with $2 \mathrm{mM}$ EDTA [17]. Cell viability was assessed via the trypan blue exclusion test. The cell viability $95 \%$ and yield of $1.5 \cdot 10^{7}$ cells $\mathrm{g}^{-1}$ are in good agreement with those previously described [17]. The cell pellets $\left(50 \mathrm{ml} 10^{7}\right.$ cells/ $\mathrm{ml}$ ) were incubated with suspension of dye-loaded liposomes or dyes/NPs complexes $(50 \mathrm{ml})$ in $1 \mathrm{ml}$ of Eagle's medium with $10 \%$ fetal calf serum at $37^{\circ} \mathrm{C}$ for required time intervals. Afterwards the non-bound liposomes or NPs were removed by centrifugation at $500 \mathrm{~g}$ and washing-out by adding HBSS (HEPES buffered saline solution) buffer (pH 7.4) with $0.1 \%$ BSA.

Cell imaging, spectroscopy and microspectroscopy. Fluorescence spectra of the solutions were taken with a spectrofluorimeter Lumina («Thermo Scientific», USA). Cell visualization was carried out using fluorescent microscope Olympus IX 71 supplied with a digital camera Olympus C-5060 with the magnification of $\times 1000$ in the conditions of oil immersion. Fluorescence was excited by a xenon lamp $75 \mathrm{~W}$ using BP 460-490 and BP $510-550 \mathrm{~nm}$ filters to excite $\mathrm{DiO}$ and DiI, respectively. To study FRET, BP 460-490 filter was used. Microspectroscopy in the area of interest was carried out using spectral detector USB 4000 (Ocean Optics) connected with Olympus IX71.

Results and discussion. Nanocarriers interaction with model cell membranes. Several research groups, including ours, use the FRET based methods to in vivo and in vitro study on the release of lipophilic agents from polymeric micelles [18, 19], kinetic and dynamic stability of polymeric micelles [20], liposomal vesicles interaction with cells of different types in dynamics [15]. A FRET pair, DiO as the energy donor and DiI as the energy acceptor, was used for these purposes. When both FRET molecules were encapsulated in one nanocarrier (liposome, micelle, nanoparticle), and excited at the appropriate wavelength, the energy transfer occurred due to the close proximity between the dyes: excitation at $460 \mathrm{~nm}$ (donor excitation) resulted in a very strong emission at $565 \mathrm{~nm}$ (acceptor emission), Fig. 2, curve 1 . When nanocarriers are broken down for any reason (for instance, in case of organic solvent DMF addition), the donor and acceptor molecules are released and diffuse apart, eliminating the energy transfer [12, $14,15]$. In such a case, a redistribution of the donor $\left(\lambda_{\max }=501 \mathrm{~nm}\right)$ and acceptor $\left(\lambda_{\max }=565 \mathrm{~nm}\right)$ peaks was

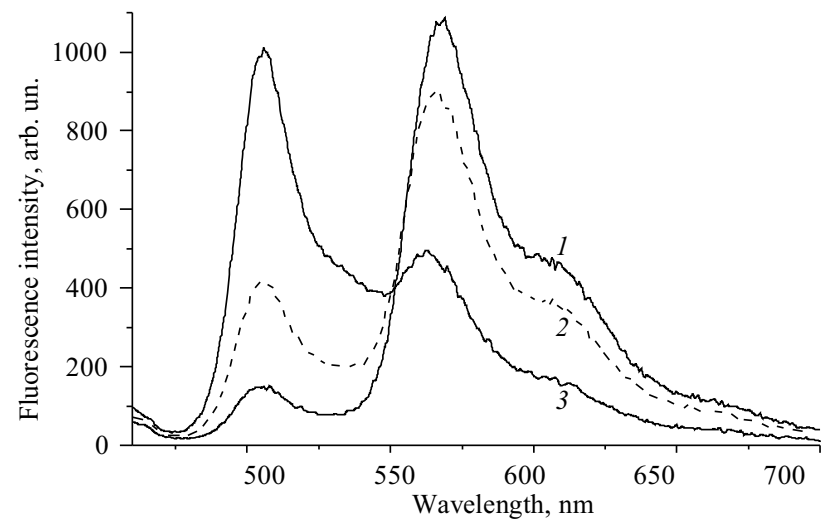

Fig. 2. Redistribution of the donor and acceptor fluorescence relative intensities in solutions containing dyes-loaded PC liposomes and different amounts of DMF: 1 - without DMF; $2-30 \%$ of DMF; $3-80 \%$ of DMF; $\lambda_{\text {exc }}=460 \mathrm{~nm}$

observed (Fig. 2, curves 2,3). The $\lambda$-ratiometry method is based on the analysis of the FRET ratio $I_{D i l} /\left(I_{D i O}+I_{D i I}\right)$ where $I_{D i I}$ and $I_{D i O}$ are the fluorescence intensities measured at DiI and DiO maxima, respectively [13].

At the first stage of our research, we studied the kinetics of lipophilic dyes release under the nanocarriers interaction with the model cell membranes. A concentrated suspension of PC liposomes $\left(1 \cdot 10^{-2} \mathrm{M}\right)$, which do not contain dye molecules, was used as a model system of cell membranes [21]. Colloidal solutions of nanocarriers (PC liposomes, SDS micelles, $\mathrm{GdYVO}_{4}: \mathrm{Eu}^{3+}$ or $\mathrm{CeO}_{2} \mathrm{NPs}$ ) containing FRET-dyes were mixed with the concentrated suspension of liposomes (1:1 ratio) and kept at room temperature during the desired time intervals (from $30 \mathrm{~min}$ up to $170 \mathrm{~h}$ ). Schematic representation of the experiment is presented on Fig. 3. A decrease of FRET ratio was observed over time for all nanocarries under study, but with different efficiency (Fig. 4). At the same time, in the solutions of nanocarries diluted at the ratio 1:1 with double distilled water without lipids we did not observe any redistribution in time of the donor and acceptor fluorescence. These results indicate the nanocarriers interaction with the lipid bilayers of model membranes and lipophilic dyes release as well as dilution in lipid phase that leads to an increase in the donor-acceptor distance and, consequently, the FRET ratio decrease (Fig. 4).

The SDS micelles exhibit high stability in liposomal suspension. The FRET ratio $I_{D i l} /\left(I_{D i O}+I_{D i I}\right)$ changed very slowly (Fig. 4, curve 1 ). Curve 1 reached a plateau only after $120 \mathrm{~h}$. Meanwhile, the FRET ratio chan- 


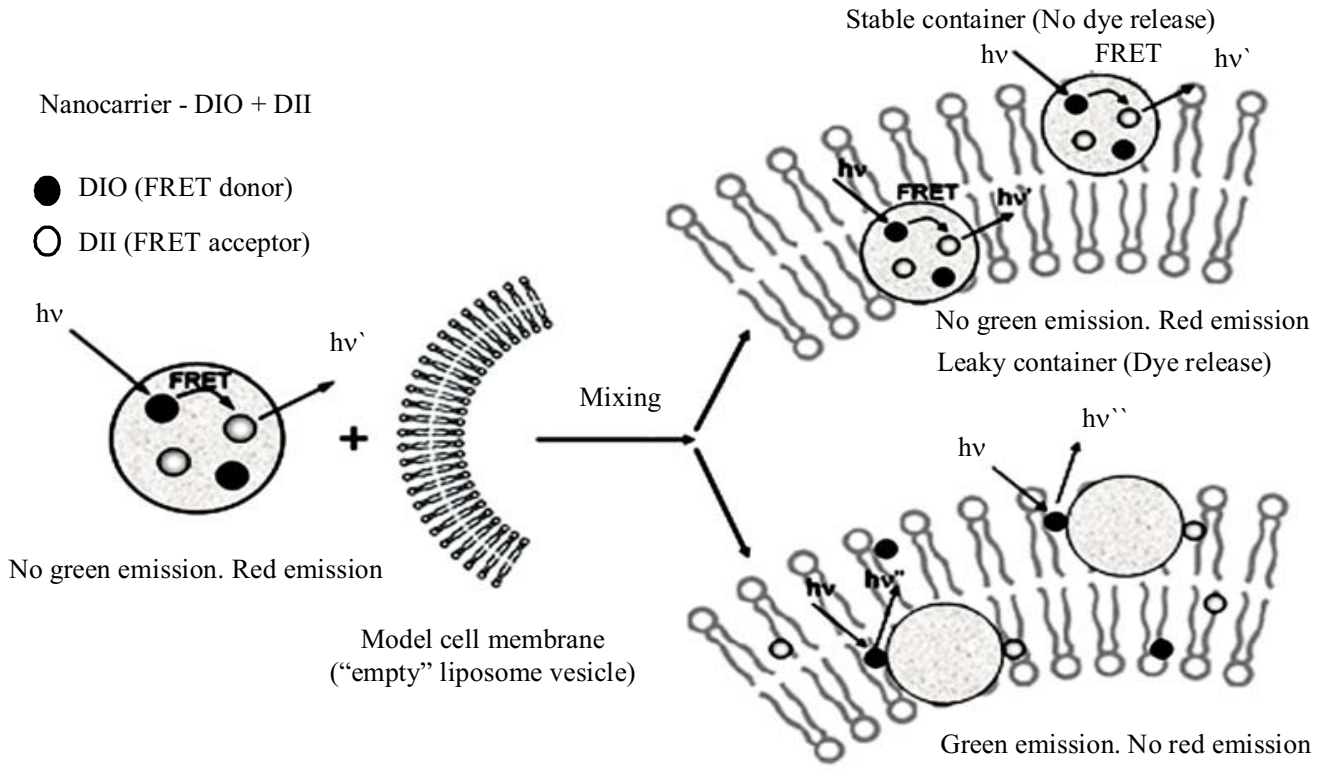

Fig. 3. Schematic representation of the experiment

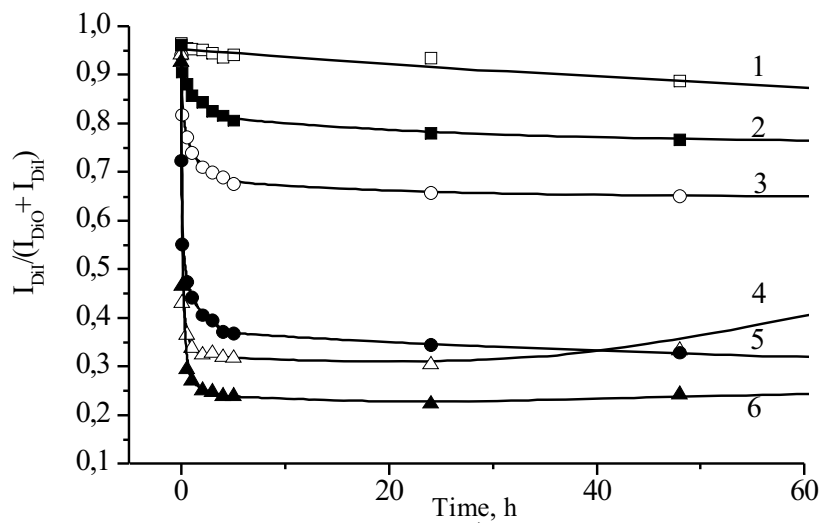

Fig. 4. Time traces of FRET ratio $I_{D i l} /\left(I_{D i O}+I_{D i l}\right): 1-$ SDS micelles; $2-$ liposomes $+10 \%$ of SDS; 3 - liposomes; 4 - GdYVO $: \mathrm{Eu}^{3+} ; 5$ $\mathrm{GdYVO}_{4}: \mathrm{Eu}^{3+}+$ cholesterol; $6-\mathrm{CeO}_{2}$

ged from 0.98 to 0.82 that indicates a very low efficiency of hydrophobic cationic dyes release from the anionic nanocarriers into the lipid phase.

The process of redistribution of the dyes between nanocarriers and the lipid phase can be described by firstorder reaction kinetics in the following form [20, 22]:

$$
\left(\frac{I_{D i I}}{I_{D i O}+I_{D i I}}\right)_{(t)}=\left(\frac{I_{D i I}}{I_{D i O}+I_{D i I}}\right)_{(0)} e^{-K t},
$$

where $K-$ is the release rate constant (the dye leakage coefficient).

First-order reaction kinetics can be assumed when the reaction rate depends on the concentration of only one reactor, in our case, on the lipid phase concentration. A nonlinear fit (eq. 1) of the FRET ratio changes was generated by the method of last-squares and allows $K=0.008 \mathrm{~h}^{-1}$ to be obtained (Table 1 ).

For first-order reactions one can also use the dye release half-life (in our case, time for the initial FRET ratio to be reduced by $1 / 2$ ), which can be obtained as [20]:

$$
t_{1 / 2}=\frac{\ln 2}{K} .
$$

For SDS micelles, the dye release half-life was estimated to be $86 \mathrm{~h}$ that is rather large value indicating a low efficiency of the dye molecules release from SDS micelles. We suggest that this fact can be explained by the key role of electrostatic interactions, which hold cationic dyes in oppositely charged micelles and prevent their release into the lipid bilayers of the model cell membranes.

For other nanocarriers under study the dye release process was much faster (Table 1). The FRET ratio changed within about $5 \mathrm{~h}$ and then all the curves reached a plateau (Fig. 4). For PC liposome nanocarriers the dye leakage coefficient was obtained to be $0.82 \mathrm{~h}^{-1}$, while $t_{1 / 2}$ is $0.85 \mathrm{~h}$ (Fig. 4, curve 3, Table 1). To test a role of electrostatic interactions, we added $10 \%$ of SDS in the lipid bilayers of liposomal containers that provided a negative charge of liposome without changing its properties. As seen in Table 1, $t_{1 / 2}$, becomes about three times higher that confirms the role of electrostatic interactions in the dye-to-nanocarrier binding. 
Table 1

Dye release constant $(K)$ and half-life $\left(t_{1 / 2}\right)$ in model cell membranes

\begin{tabular}{ccc}
\hline Type of nanocarriers & $K, \mathrm{~h}^{-1}$ & $t_{1 / 2}, \mathrm{~h}$ \\
\hline SDS micelles & 0.008 & 86 \\
Liposomes & 0.82 & 0.85 \\
Liposomes $+10 \%$ SDS & 0.29 & 2.4 \\
$\mathrm{GdYVO}_{4}: \mathrm{Eu}^{3+}$ & 1.96 & 0.36 \\
$\mathrm{GdYVO}_{4}: \mathrm{Eu}^{3+}+\mathrm{cholesterol}^{\mathrm{CeO}}$ & 0.75 & 0.93 \\
\hline
\end{tabular}

Table 2

Dye release constant $(K)$ and half-life $\left(t_{1 / 2}\right)$ in rat hepatocytes

\begin{tabular}{c|c|c}
\hline Type of nanocarriers & $K, \mathrm{~h}^{-1}$ & $t_{1 / 2}, \mathrm{~h}$ \\
\hline $\mathrm{CeO}_{2}$ & 3.1 & 0.22 \\
$\mathrm{GdYVO}_{4}: \mathrm{Eu}^{3+}$ & 0.54 & 1.28 \\
Liposomes & 0.9 & 0.77 \\
\hline
\end{tabular}

In case of $\mathrm{GdYVO}_{4}: \mathrm{Eu}^{3+}$ and $\mathrm{CeO}_{2} \mathrm{NPs}$, a very fast release of dyes from the dyes/NP complexes and their transition into the lipid phase were observed (Fig. 4, curves 4,6 ). The $\mathrm{K}$ values are large, whereas the dye release half-lives are less than $30 \mathrm{~min}$ (Table 1). Such effects could be explained by the appearance of lipophilic gradient and fast transition of lipophilic dyes DiO

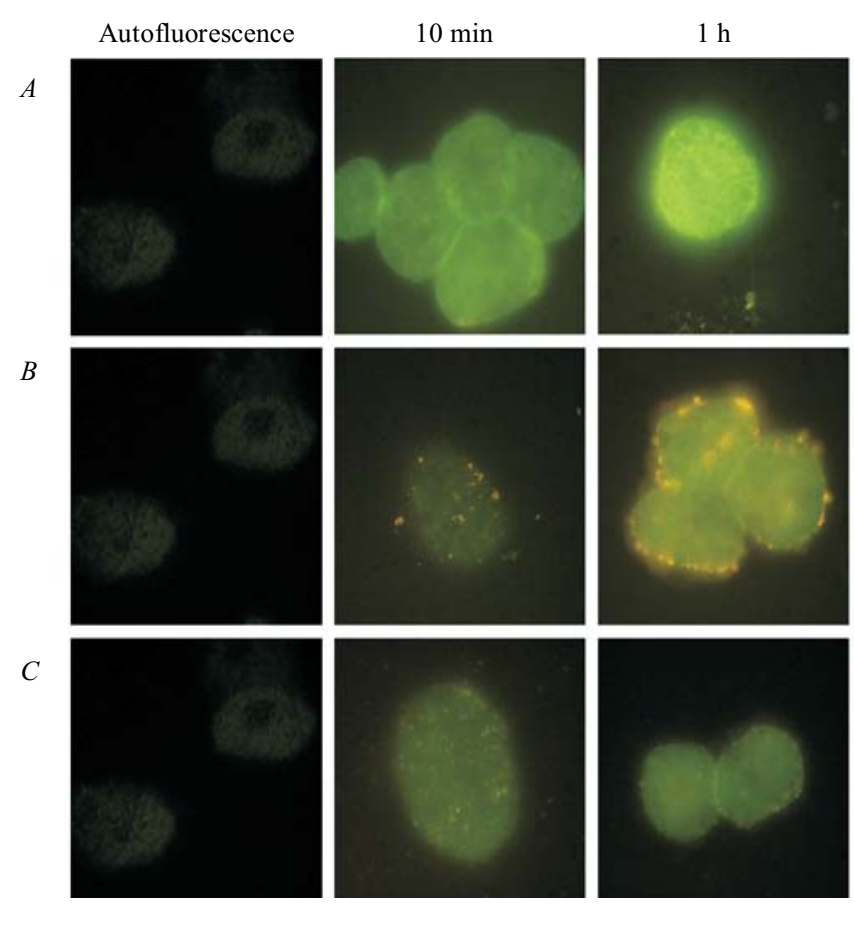

and DiI into the lipophilic environment. If nanocarriers contain encapsulated cholesterol, the process of dye release slowed down by almost in three times by reducing the lipophilic gradient in such a solution (Table 1).

Nanocarriers interaction with living cells in vitro.To test nanocarriers in the experiments with living cells, freshly isolated rat hepatocytes were used. Fig. 5, A, shows the fluorescent images of rat hepatocytes obtained at different time intervals of cell incubation with the dyes $/ \mathrm{CeO}_{2}$ complexes. A gradual increase in cell brightness over time was observed that points to the dyes accumulation in a cell membrane. At the same time, we observed a decrease in the FRET ratio, $I_{D i l} /\left(I_{D i O}+\right.$ $+\mathrm{I}_{\text {Dil }}$ ), over time (Fig. 6, curve 3) from 0.7 to 0.2 that points to an increase of the distance between the donor and acceptor molecules due to their diffusion in the lipid bilayers of cell membranes. Similarly to the model cell membranes, the process of the donor and acceptor fluorescence redistribution took about five hours and then curve 3 reached the plateau (Fig. 6). The dye release kinetic parameters are $K=3.1 \mathrm{~h}^{-1}$ and $t_{1 / 2}=0.22 \mathrm{~h}$ that agrees well with those obtained for the model cell membranes (Table 2).

Features of the $\mathrm{GdYVO}_{4}: \mathrm{Eu}^{3+}$ nanocarriers interaction with the living cells differs from that for the $\mathrm{CeO}_{2}$ nanocarriers. As shown in Fig. 5, $b$, at the short time incubation, $10 \mathrm{~min}$ and $1 \mathrm{~h}$, the dyes are located mainly
$3 \mathrm{~h}$
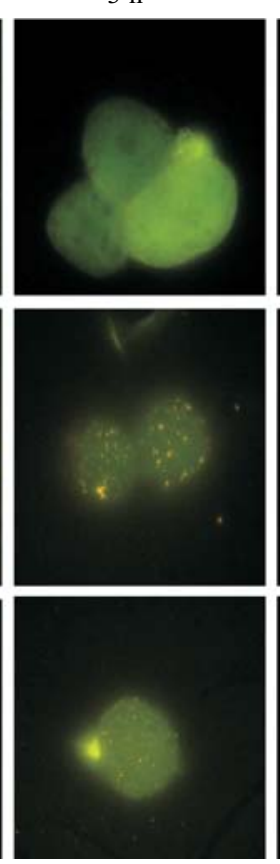

$24 \mathrm{~h}$
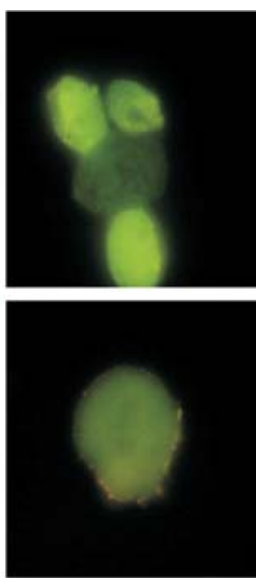

Fig. 5. Fluorescent images of rat hepatocytes taken at different times of cell incubation with dyes $/ \mathrm{CeO}_{2}$ $(A)$, dyes $/ \mathrm{GdYVO}_{4}: \mathrm{Eu}^{3+}(B)$ complexes and dyes-loaded liposomes $(C)$. Excitation with BP 460-490 filter 


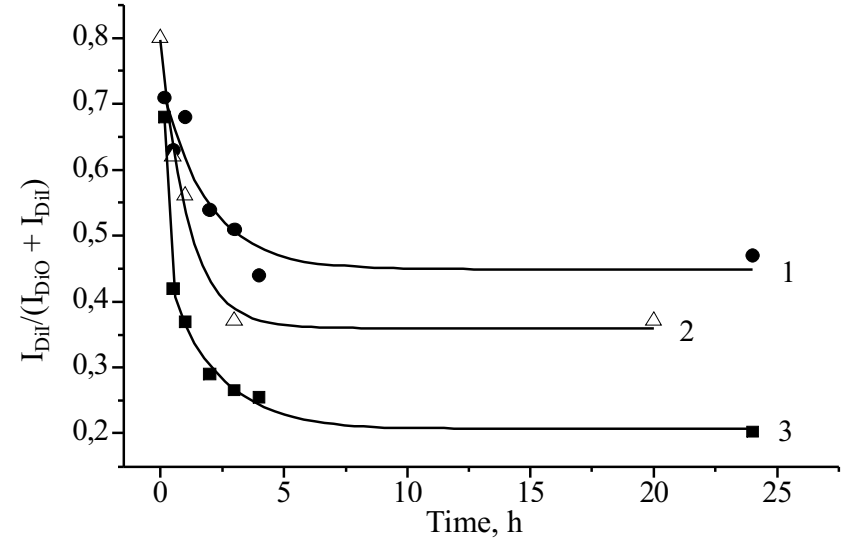

Fig. 6. Time traces of FRET ratio $I_{D i} /\left(I_{D i O}+I_{D i I}\right)$ in red hepatocytes: 1 GdYVO $:_{4} \mathrm{Eu}^{3+} ; 2-\mathrm{PC}$ liposomes; $3-\mathrm{CeO}_{2}$

on the cell membrane surface (yellow spots). At the same time, even after $24 \mathrm{~h}$ incubation of the cells with the dyes/GdYVO $\mathrm{Gu}^{3+}$ complexes, the FRET ratios changed not sufficiently (from 0.7 to 0.5 ) and the yellow spots were still observed. The dye release half-life was almost six times higher than in case of the $\mathrm{CeO}_{2}$ nanocarriers (Table 2) and the obtained kinetic parameters $K$ and $t_{1 / 2}$ also differed from those obtained in the model cell membranes (Table 1). We can ascribe these facts to the specificity of the GdYVO : $^{3+} \mathrm{NPs}$ interaction with living cells. As it was mentioned above, spherical GdYVO ${ }_{4}: \mathrm{Eu}^{3+} \mathrm{NPs}(d=2 \mathrm{~nm})$ exhibit the penetration into cells and accumulation in cell organelles [10]. We suppose the yellow spots to be the dyes/GdYVO $: \mathrm{Eu}^{3+}$ complexes accumulated either on a cell membrane surface or inside the cells similarly to the dyes accumulation in the cells endocytosis vesicles after their internalization revealed by Chen and co-workers [18, 19].

For comparison, the kinetic parameters of dye-loaded PC liposomes interaction with rat hepatocytes were also analyzed. The fluorescent images of cells taken in different time periods show a gradual increase in cell brightness over time, no spots on the cell membranes were observed that points to the effective dye release from the liposomes (Fig. 5, c). The FRET ratio changed and the kinetic parameters $K$ and $t_{1 / 2}$ were similar to those obtained for the model cell membranes (Fig. 6, $c$, Table 2).

Controlled release of drugs and other bioactive agents is a key point in drug formulation pharmacokinetic study and attract many researches $[11,21,23]$. Controlled drug delivery applications include both a one-time or sustained targeted delivery [21-24]. Controlled-release systems are designed to enhance drug therapy due to reducing the amount of drug necessary to cause the same therapeutic effect in patient. Over the years of controlled release research, different systems have been explored to get predesigned release profile [11, 21-24]. In certain drug administration strategies, a fast release of drug immediately upon placement in the release medium is required [11]. We have shown that NPs as a platform for drug delivering can provide fast lipophilic content release from the nanocarrier, Table 1. However, specificity of GdYVO $:_{4} \mathrm{Eu}^{3+} \mathrm{NPs}$ interaction with rat hepatocytes affect the kinetics of this process increasing the value (Table 2). Meanwhile, the rate of lipophilic content release can be controlled by decreasing lipophilic gradient and providing Coulombic interactions between the nanocarrier and the encapsulated substance.

Conclusions. The FRET-based method was used to study the nanocarriers interaction with the model cell membranes and living cells in dynamic experiments in vitro. The dye release constants $(K)$ and half-lives $\left(t_{1 / 2}\right)$ were analyzed for different nanocarriers (SDS micelles, PC liposomes, GdYVO $: \mathrm{Eu}^{3+}$ and $\mathrm{CeO}_{2} \mathrm{NPs}$ ). GdYVO $: \mathrm{Eu}^{3+}$ and $\mathrm{CeO}_{2}$ NPs were shown to provide a faster lipophilic dyes release in the model cell membranes as compared to PC liposomes, the dye release half-life $t_{1 / 2}$ is less than $30 \mathrm{~min}$, that can be explained by the appearance of a lipophilic gradient. The negatively charged or lipophilic compounds can decrease the rate of lipophilic agents release from nanocarriers $i$. e. allow this process to be controlled. Our experiments confirm the specificity of the $\mathrm{GdYVO}_{4}: \mathrm{Eu}^{3+} \mathrm{NPs}$ interaction with living cells. We suppose the intracellular uptake of the dyes/GdYVO ${ }_{4}: \mathrm{Eu}^{3+} \mathrm{NPs}$ complex with a slower dye release, whereas for the dyes $/ \mathrm{CeO}_{2}$ complex the dye release pattern is similar to that in case of the model cell membranes.

Динаміка вилучення барвників 3 наноконтейнерів різного типу в модельних мембранах і живих клітинах

Т. М. Ткачова, С. Л. Єфімова, В. К. Клочков, А. В. Сорокін, Ю. В. Малюкін

Резюме

Мета. Вивчення динаміки вилучення ліпофильного вмісту з наноконтейнерів різного типу, органічних молекулярних ансамблів $i$ неорганічних наночастинок (НЧ) в експериментах in vitro. Mето- 
ди. Двоканальний ратіометричний метод реєстрачії інтенсивності флуоресиениії із застосуванням безвипромінювального перенесення енергії електронного збудження, метод флуоресиентної спектроскопії і мікроспектроскопії. Результати. Вивільнення ліпофильных барвників з органічних (ліпосоми і міцели) і неорганічних (на основі НЧ $\mathrm{GdVO}_{4}: \mathrm{Eu}^{3+}{ }_{\mathrm{i}} \mathrm{CeO}_{2}$ ) наноконтейнерів може бути описано кінетичною реакиією першого порядку як у модельних клітинних мембранах, так і в живих клітинах. Отримано константи швидкості вивільнення $(K)$ i час напіввиведення $\left(t_{1 / 2}\right)$ барвників. Висновки. Наноконтейнери на основі НЧ GdYVO $: \mathrm{Eu}^{3+} i$ $\mathrm{CeO}_{2}$ забезпечують швидше вивільнення ліпофильного вмісту в модельних клітинних мембранах порівняно з ліпосомами. Проте додавання негативно заряджених або ліпофильних компонент у систему знижує швидкість вивільнення барвників. Виявлено специфічність взаємодії НЧ GdYVO : $^{3+}{ }^{3+}$ з гепатоцитами щурів.

Ключові слова: наноконтейнери, безвипромінювальне перенесення енергії, наночастинки, вивільнення барвника, модельні клітинні мембрани, живі клітини.

Динамика высвобождения красителей из наноконтейнеров различного типа в модельных мембранах и живых клетках

Т. Н. Ткачева, С. Л. Ефимова, В. К. Клочков, А. В. Сорокин, Ю. В. Малюкин

Резюме

Цель. Изучение динамики высвобождения липофильного содержимого из наноконтейнеров различного типа, органических молекулярных ансамблей и неорганический наночастиц (НЧ) в экспериментах іn vitro. Методы. Использовали двуканальный ратиометрический метод регистрайии интенсивности флуоресиенции на основе безызлучательного переноса энергии электронного возбуждения, а также метод флуоресиентной спектроскопии и микроспектроскопии. Результаты. Выход липофильных красителей из органических (липосомы и мицеллы) и неорганических (на основе $\mathrm{HY} \mathrm{GdYVO}_{4}: \mathrm{Eu}^{3+}$ и CеO $)_{2}$ наноконтейнеров может быть описан кинетической реакцичеи первого порядка как в модельных клеточных мембранах, так и в живых клетках. Получены константы скорости высвобождения $(K)$ и время полувыведения $\left(t_{1 / 2}\right)$ красителей. Выводы. Наноконтейнеры на основе НЧ GdYVO $:$ Eu $^{3+} u$ $\mathrm{CeO}_{2}$ обеспечивают более быстрое высвобождение липофильного содержимого в модельных клеточных мембранах по сравнению с липосомами. Однако добавление отрицательно заряженных или липофильных компонент в систему снижаает скорость высвобождения красителей. Обнаружена специффичность взаимодействия НЧ GdYVO : $^{3+}$ с гепатоцитами крыс.

Ключевые слова: наноконтейнеры, безызлучательный перенос энергии, наночастицы, высвобождение красителя, модельные клеточные мембраны, живые клетки.

\section{REFERENCES}

1. Hunziker P. Nanomedicine: shaping the future of medicine. Eur J Nanomed. 2012;2(1):4.

2. Bamrungsap S, Zhao Z, Chen T, Wang L, Li C, Fu T, Tan W. Nanotechnology in therapeutics: a focus on nanoparticles as a drug delivery system. Nanomedicine (Lond). 2012;7(8):1253-71.

3. Parveen S, Misra R, Sahoo SK. Nanoparticles: a boon to drug delivery, therapeutics, diagnostics and imaging. Nanomedicine. 2012;8(2):147-66.

4. Torchilin VP. Targeted pharmaceutical nanocarriers for cancer therapy and imaging. AAPS J. 2007;9(2):E128-47.
5. Liu Y, Niu T-S, Zhang L, Yang J-S. Review on nano-drugs. Natural Science. 2010; 2(1); 41-8.

6. Zhang L, Gu FX, Chan JM, Wang AZ, Langer RS, Farokhzad $O C$. Nanoparticles in medicine: therapeutic applications and developments. Clin Pharmacol Ther. 2008;83(5):761-9.

7. Klochkov VK. Coagulation of luminescent colloid $n$ GdVO4:Eu solutions with inorganic electrolytes. Functional Materials. 2009; 16(2):141-4.

8. Tkacheva TN, Yefimova SL, Klochkov VK, Sorokin AV, Borovoy $I A$, Malyukin $Y u V$. Spectroscopic study of inorganic nanoparticles nGdYVO4:Eu3+ and organic carbocyanin dyes interactions in aqueous solutions. Biophysical Bulletin. 2012; 1: 12-9.

9. Klochkov VK, Grigorova AV, Sedyh OO, Malyukin YuV. The influence of agglomeration of nanoparticles on their superoxide dismutase-mimetic activity. Colloids Surf A Physicochem Eng Asp. 2012; 409:176-82.

10. Klochkov V, Kavok N, Grygorova G, Sedyh O, Malyukin Y. Size and shape influence of luminescent orthovanadate nanoparticles on their accumulation in nuclear compartments of rat hepatocytes. Mater Sci Eng C Mater Biol Appl. 2013;33(5):2708-12.

11. Huang X, Brazel CS. On the importance and mechanisms of burst release in matrix-controlled drug delivery systems. J Control Release. 2001;73(2-3):121-36.

12. Lakowicz JR. Principles of Fluorescence Spectroscopy. New York etc., Kluwer Acad./Plenum Publ., 1999; 698 p.

13. Demchenko AP. The concept of $\lambda$-ratiometry in fluorescence sensing and imaging. J Fluoresc. 2010;20(5):1099-128.

14. Yefimova SL, Lebed AS, Guralchuk GYa, Sorokin AV, Kurilchenko IYu, Kavok NS, Malyukin YuV. Nano-scale liposomal container with a «signal system» for substances delivering in living cells. Biopolym Cell. 2011; 27(1):47-52.

15. Yefimova SL, Kurilchenko IYu., Tkacheva TN, Kavok NS, Todor IN, Lukianova NYu, Chekhun VF, Malyukin YuV. Microspectroscopic study of liposome-to-cell interaction revealed by Forster resonance energy transfer. $J$ Fluoresc. 2014; 24(2):403-9.

16. Mui B, Chow L, Hope MJ. Extrusion technique to generate liposomes of defined size. Methods Enzymol. 2003;367:3-14.

17. Wang SR, Renaud G, Infante J, Catala D, Infante R. Isolation of rat hepatocytes with EDTA and their metabolic functions in primary culture. In Vitro Cell Dev Biol. 1985;21(9):526-30.

18. Chen H, Kim S, He W, Wang H, Low PS, Park K, Cheng JX. Fast release of lipophilic agents from circulating PEG-PDLLA micelles revealed by in vivo forster resonance energy transfer imaging. Langmuir. 2008;24(10):5213-7.

19. Chen H, Kim S, Li L, Wang S, Park K, Cheng JX. Release of hydrophobic molecules from polymer micelles into cell membranes revealed by Forster resonance energy transfer imaging. Proc Natl Acad Sci USA. 2008;105(18):6596-601.

20. Lu J, Owen SC, Shoichet MS. Stability of self-assembled polymeric micelles in serum. Macromolecules. 2011;44(15):60026008 .

21. Torchilin $V$, Weissig $V$. Liposomes. A practical approach. New York: Oxford Univ. Press, 2003; 396 p.

22. Pasa G, Mishra US, Tripathy NK, Sahoo SK, Mahapatra AK. Formulation development and evoluation of didanosine sustained-release matrix tablets using HPMC K15. Int. J. Pharm. 2012; 2(1):97-100.

23. Fundamentals and applications of controlled release drug delivery. Eds J Siepmann, RA Siegel, MJ Rathbone. Advances in Delivery Science and Technology. Springer, 2012; 19-43.

24. Griffith LG. Polymeric biomaterials. Acta Mater. 2000; 48(1): 263-77.

Received 02.04.14 